\title{
The Influence of Traditional Markets and Modern Markets Growth on the Performance of the Retail Business Sector
}

\author{
Sri Iswati ${ }^{1}$, Pudji Astuty ${ }^{2}$, Yolanda $^{3}$ \\ \{iswati.ssri@gmail.com ${ }^{1}$,pudji_astuty@borobudur.ac.id², yolanda@borobudur.ac.id ${ }^{3}$ \} \\ Universitas Borobudur, Jakarta, Indonesia ${ }^{1,2,3}$
}

\begin{abstract}
This research aims to determine how far the response of retail performance is associated with indicators of the number of workers on the growth of traditional markets and modern markets, related to turnover of goods and selling prices of goods. The method used in this research is quantitative with the operationalization of the growth variable in the modern market and traditional market $(\mathrm{X})$ on the performance variable $(\mathrm{Y})$. The results obtained from this study are that the sales turnover of conventional and modern markets significantly experienced a significant difference in retail performance compared to the growth of the two markets experienced a very substantial difference.
\end{abstract}

Keywords: Traditional Market; Modern Market; Retail Performance

\section{Introduction}

Every town's economics and socio-culture are reflected in the market as a sort of public service where commodities are bought and sold for the community. The market has developed through time in terms of the location and administration, from traditional to contemporary, as the times have changed [1]. The development of shopping places in cities in the world, both in Western and Asian countries, all go through stages, starting from traditional markets, which then undergo a modernization process to become department stores (convenience stores), chain stores, shopping centers, department stores, stores supermarkets. This modernization process is inseparable from changes in demographic patterns, professional specialization, diversification, socio-economic structures, and changes in community culture [2]. Directly in the retail business sector opened in 1998. Increased competition has encouraged the emergence of supermarkets in cities [3].

Small to find new customers and a price war ensues. As a result, Indonesian supermarkets only served the upper-middle class in the 1980s and early 1990s [4]. The proliferation of supermarkets in small towns and the practice of predation through price-cutting strategies allow lower-middle-class consumers to access supermarkets [5]. In addition, the community also experienced changes in the choice of places to buy daily necessities, namely a shift in lifestyle from traditional to modern. As a result, consumer purchasing habits have shifted [6]. The fast growth of contemporary markets has resulted in a rise in the number of retail 
establishments. The amount of shopping options is a big factor in deciding on a great alternative shopping spot. In addition to the large number, the heterogeneity of shopping places is also increasingly complex, making it very difficult to choose a good shopping place that suits your needs [7].

Traditional markets' function has lately evolved due to the introduction of modern markets such as minimarkets, supermarkets, and hypermarkets [8]. Many folks, particularly those in metropolitan regions, have found that shopping at modern markets has met their daily or family needs. Consumers perceive modern markets to be more profitable since they provide a variety of shopping options with nice amenities [9]. Customer requirements have been captured, and current marketplaces have been able to suit consumer desires and tastes. Traditional markets, on the other hand, have been reluctant to adjust to more dynamic changes in consumer buying behavior. As a result, shoppers' purchasing habits have evolved and switched to modern markets. People used to buy for their daily requirements at traditional markets, but today they prefer to shop at modern marketplaces. Modern markets can develop quickly, while conventional markets are slow to respond [10].

The existence of modern shopping centers such as minimarkets, supermarkets, and hypermarkets has slightly disturbed traditional markets. The similarity of functions that modern shopping centers and traditional markets own has led to competition. The proliferation of contemporary shopping centers is feared to kill traditional markets that reflect the people's economy. The number of modern markets tends to experience favorable growth from time to time, while traditional markets tend to experience negative growth. The number of contemporary trade centers in Indonesia, both hypermarkets, supermarkets, minimarkets, and convenience stores, has increased by around 23,000 units.

In contrast, the existence of traditional markets in Indonesia has been eroded from year to year by the spread of modern markets. The presence of conventional markets for four years was reduced to 3,000 units which caused thousands of people to lose their livelihoods. Data from the Indonesian Market Traders Association (IKAPPI) states that the number of traditional markets throughout Indonesia has fallen drastically from 13,540 to 9,950 needs within four years. The decline in the growth of traditional markets and the development of other modern markets increasingly shows a shift in people's preferences in meeting their daily needs. This is, of course, a big question. What happened is that nowadays, people tend to choose the modern market over the traditional market. The product's price in the conventional market is lower, but the price difference is not too much compared to the price in the modern market.

\section{Methodology}

The approach utilized in this study is quantitative, with the growth variable in the contemporary market $(\mathrm{Y})$ and the conventional market $(\mathrm{X})$ on the performance variable being operationalized (Y). The location of this research was carried out in Jakarta during the year 2020 or during the COVID-19 pandemic. by using indicators of sales turnover, the selling price of goods, and the number of workers. 


\section{Results and Discussion}

\begin{tabular}{lcccccc}
\hline \multirow{2}{*}{ Ino } & Indicator & \multicolumn{5}{c}{ Perception } \\
\cline { 3 - 7 } & & Very bad & Bad & Currently & Good & Very Good \\
\hline 1 & Ease of Access & - & $6 \%$ & $43 \%$ & $46 \%$ & $5 \%$ \\
2 & Limited Facilities & - & - & $20 \%$ & $60 \%$ & $20 \%$ \\
3 & Shopping Habits & - & - & $22 \%$ & $56 \%$ & $22 \%$ \\
\hline
\end{tabular}

The variations in features between contemporary market management and old markets may be viewed from the management institutions' perspective. In traditional markets, the Market Service, which is part of the bureaucratic system, is in charge of managing management institutions. At the same time, modern needs are usually managed by professionals with a business approach. In addition, traditional market management systems are generally decentralized, where each trader works their business system. Meanwhile, in the modern market, the management system is more centralized, which allows the parent manager to set the standard for managing its business. I was observing the primary substance of the policies that have been issued (human resources). The results of the data normality test (sales turnover, selling price of goods, and the number of workers) are presented in the table below.

Table 1. Result of Data Normalities

\begin{tabular}{lllllc}
\hline 1 & Sales Turnover & 0,112 & 100 & & Non Sig \\
2 & Selling Price of Goods & 0,121 & 100 & 0,146 & Non Sig \\
3 & Total manpower & 0,289 & 100 & 0,000 & Sig \\
\hline
\end{tabular}

The test results indicate that the data on sales turnover and product selling prices are normally distributed. These two data are then tested for the difference in average using the ttest. While the information on the number of workers showed that it was not normally distributed, so it was tested using the Mann-Whitney U test.

Table 2. Different Test Results

\begin{tabular}{cccccc}
\hline 1 & Selling price & T-test & 0,54 & 0.593 & Non \\
2 & Total Power & Mann & 1 & 0.079 & Non \\
\hline
\end{tabular}

From the different test results above, it can be seen that only sales turnover (traditional markets) are proven to be significantly different (have an average difference) between before and after the modern market. At the same time, the other two aspects, namely the selling price of goods and the number of workers, did not show a significant difference. To find out the average comparison of the three research indicators can be seen in the following table:

Table 3. Comparison of Average Sales Turnover, Selling Price of Goods, and Number of Workers in Traditional Markets Before and After the Modern Market

\begin{tabular}{llllcc}
1 & Sales Turnover & 4.5109 & $>1.1746$ & Sig \\
2 & Selling Price of Goods & 3.4682 & $>$ & 3.0675 & Non \\
3 & Total manpower & 3.0168 & $>$ & 2.9807 & Non \\
\hline
\end{tabular}




\section{Conclusion}

Several government policies have been issued to regulate market management, both modern and traditional markets. The implementation of this policy requires a more significant commitment so that it can be implemented consistently. On a macro level, several research results show that modern markets have threatened the existence of traditional markets. This fact was revealed, among others, in AC Nielson's research which stated that the current market had grown by $31.4 \%$. Simultaneously, traditional markets have increased negatively by $8 \%$. Based on this fact, traditional markets will run out in about 12 years, so it is necessary to take preventive measures to maintain the continuity of traditional markets, including the continuity of trading (retail) businesses managed by cooperatives and SMEs.

According to the findings of this study, the emergence of contemporary marketplaces has a negative influence on traditional markets in terms of decreased sales turnover. The study findings suggest that among the three variables tested, using a different test with a significance threshold of $\mathrm{a}=0.05$. The old market's sales turnover variable results in a large difference before and after the modern market's presentation. The turnover after the contemporary market was lower than before the presence of the current market. Modern market, while other variables, namely the number of workers and the selling price of goods, did not show a significant difference.

\section{References}

[1] E. E. Supriyanto, Eksistensi Nilai-Nilai Pancasila Dalam Kebijakan Ekonomi Indonesia, 1st ed., no. September. Malang: Literasi Nusantara, 2020.

[2] A. Susilo, "Dampak Keberadaan Pasar Modern Terhadap Usaha Ritel Koperasi / Waserda Dan Pasar," J. Ilmu Ekon., vol. 3, no. 1, pp. 1-9, 2016.

[3] J. Sengupta, "Digital Banking in Asia Winning approaches in a new generation of financial services," Asia Financ. Institutions, pp. 1-89, 2014.

[4] R. K.-K. Sitepu, "Dampak Keberadaan Pasar Modren Terhadap Kinerja Ekonomi Regional," Quant. Econ. J., vol. 1, no. 1, pp. 1-17, 2020, doi: 10.24114/qej.v1i1.17399.

[5] I. DEVY PRAMUDIANA, "Perubahan Perilaku Konsumtif Masyarakat Dari Pasar Tradisional Ke Pasar Modern," Asketik, vol. 1, no. 1, pp. 35-43, 2017, doi: 10.30762/ask.v1i1.409.

[6] R. S. Dewi, "PENGARUH FAKTOR MODAL PSIKOLOGIS, KARAKTERISTIK ENTREPRENEUR, INOVASI, MANAJEMEN SUMBER DAYA MANUSIA, DAN KARAKTERISTIK UKM TERHADAP PERKEMBANGAN USAHA PEDAGANG DI PASAR TRADISIONAL (Studi kasus pada Pedagang Sembako dan Snack di Pasar Peterongan)," J. Adm. Bisnis, vol. 2, no. 1, pp. 29-40, 2013, doi: 10.14710/jab.v2i1.5352.

[7] M. A. Ananda, "DAMPAK KEBERADAAN RITEL MODERN TERHADAP PEREKONOMIAN PASAR TRADISIONAL DI ACEH BARAT DAN NAGAN RAYA M. Aditya Ananda, MA Dosen Perbankan Syariah, STAIN Tgk Dirundeng Meulaboh," At-Tasyri', vol. 11, no. 2, pp. 89-102, 2019.

[8] O. Moechtar, "Pasar Modern Pada Peraturan Daerah Kota Surabaya Nomor 1 Tahun 2010 Dalam Aspek Hukum Persaingan," Yuridika, vol. 26, no. 2, pp. 151-175, 2011.

[9] D. Durianto, S. Riyadi, and F. Santiago, "Price Balance for the Good of Consumers and 
Business Actors," 2021, doi: 10.4108/eai.6-3-2021.2305979.

[10] M. Kurdi, D. Kurniawati, V. Andrianingsih, A. Furqani, N. Alfiyah, and M. Arifin, "The Government's Role in MSMEs Development Through E-Commerce in Sumenep Regency," 2021, doi: 10.4108/eai.6-3-2021.2306388. 